\title{
CHARACTERIZATION AND TREATMENT OF SISAL FIBER RESIDUES FOR CEMENT-BASED COMPOSITE APPLICATION
}

\author{
PAULO R. L. LIMA ${ }^{1}$, ROGÉRIO J. SANTOS ${ }^{2}$, SAULO R. FERREIRA ${ }^{3}$, \\ ROMILDO D. TOLEDO FILHO
}

\begin{abstract}
Sisal fiber is an important agricultural product used in the manufacture of ropes, rugs and also as a reinforcement of polymeric or cement-based composites. However, during the fiber production process a large amount of residues is generated which currently have a low potential for commercial use. The aim of this study is to characterize the agricultural residues by the production and improvement of sisal fiber, called field bush and refugo and verify the potentiality of their use in the reinforcement of cement-based composites. The residues were treated with wet-dry cycles and evaluated using tensile testing of fibers, scanning electron microscopy (SEM) and Fourier transform infrared (FTIR) spectroscopy. Compatibility with the cement-based matrix was evaluated through the fiber pull-out test and flexural test in composites reinforced with $2 \%$ of sisal residues. The results indicate that the use of treated residue allows the production of composites with good mechanical properties that are superior to the traditional composites reinforced with natural sisal fibers.
\end{abstract}

KEYWORDS: Agricultural residue, Biocomposites, Pull-out test, Fiber treatment, Flexural behavior.

\section{CARACTERIZAÇÃO E TRATAMENTO DE RESÍDUOS DE FIBRA DE SISAL PARA USO EM COMPÓSITOS À BASE DE CIMENTO}

RESUMO: A fibra de sisal é um importante produto agrícola usado na produção de cordas, tapetes e também como reforço de materiais compósitos poliméricos ou cimentícios. Durante sua produção, no entanto, é gerada uma grande quantidade de resíduos que atualmente tem pequeno potencial de aproveitamento comercial. O objetivo deste trabalho é caracterizar os resíduos agrícolas oriundos da produção e beneficiamento da fibra de sisal, denominados refugo e bucha de campo, e verificar a potencialidade de uso como reforço de argamassa. Os resíduos foram tratados com ciclos molhagem-secagem e avaliados através de ensaio de tração direta, microscopia eletrônica de varredura (MEV) e espectroscopia de infravermelho (FTIR). A compatibilidade com matriz a base de cimento foi avaliada através de ensaio de arrancamento de fibra e ensaio de flexão em compósitos reforçados com $2 \%$ de resíduos de sisal. Os resultados indicam que o uso do resíduo tratado permite a produção de compósitos com boas propriedades mecânicas, superiores aos compósitos tradicionais reforçados com fibra natural de sisal.

PALAVRA-CHAVE: Resíduo agrícola; Biocompósito; Ensaio de arrancamento; Tratamento de fibra; Comportamento a flexão.

\section{INTRODUCTION}

The development of green buildings has become increasingly important due to the very low impact on the environment compared to conventional buildings. Furthermore, these buildings are

\footnotetext{
${ }^{1}$ Eng ${ }^{\circ}$ Civil, Prof. Doutor, Programa de Pós-graduação Engenharia Civil e Ambienta,/UEFS, Av. Transnordestina, SN, Novo Horzonte, Feira de Santana - BA, Fone: (75) 3161-8117, lima.prl@pq.cnpq.br;

${ }^{2}$ Eng $^{\circ}$ Civil, Mestre, Programa de Pós-graduação Engenharia Civil e Ambienta,/UEFS, rogeriojsantos@ gmail.com;

${ }^{3}$ Tecnológo Saneamento Ambiental, Doutorando, Programa de Engenharia Civil/COPPE/UFRJ, CP 68506, CEP 21945-970, Rio de Janeiro -RJ. ferreira.sr@hotmail.com,

${ }^{4}$ Eng $^{\circ}$ Civil, Prof. Dr., Programa de Eng. Civil/COPPE/UFRJ, CP 68506, CEP 21945-970, Rio de Janeiro -RJ, toledo@ coc.ufrj.br. Recebido pelo Conselho Editorial em: 30-9-2013

Aprovado pelo Conselho Editorial em: 13-4-2014
}

Eng. Agríc., Jaboticabal, v.34, n.5, p. 812-825, set./out. 2014 
planned to be economically viable and healthy places to live and work (GHAFFARIANHOSEINI et al., 2013). This concept can also be applied to rural buildings where environmental comfort requirements are essential to ensure a higher animal welfare (FIORELLI et al., 2012) and, consequently, a greater quantity and quality of production of meat.

One of the main materials currently used in green buildings is the biocomposite: a combination of natural fibers (such as wood fibers, coir, hemp, jute, sisal, and flax) with polymer (RAMIRES et al., 2010), bitumen (ALMEIDA \& PASSINI, 2013) or cement-based matrices (FARIAS FILHO et al., 2010). Natural fibers are biodegradable, renewable and widely available in Brazil. Their use as reinforcement of cement-based matrices has added advantages such as high toughness, post-cracking performance, resistance to impact (MELO FILHO, 2005) and thermal insulation (PADILHA et al., 2001; TONOLI et al, 2011).

However, residues are generated during the production of natural fibers which have little or no commercial value. In the case of sisal fiber, after decortication (Figure 1a) only approximately $5 \%$ of the whole sisal leaf is used, leaving the remaining $95 \%$ as residue, which is separated in a rotating sieve (Figure 1b) in two types: i) leaf residues that can be used to generate bioenergy, animal feed and fertilizers productions or that are accumulated nearby rivers and streams, and ii) field bush which is composed of short sisal fiber and that currently has no application. During the drying process (Figure 1c), sisal fibers are visually selected; those fibers which have no damage or impurities are then brushed and packed for export or are used as basic material for sisal-based products. The other fibers, called refugo, are used in construction industry as by-products in the installation of ceiling plaster.
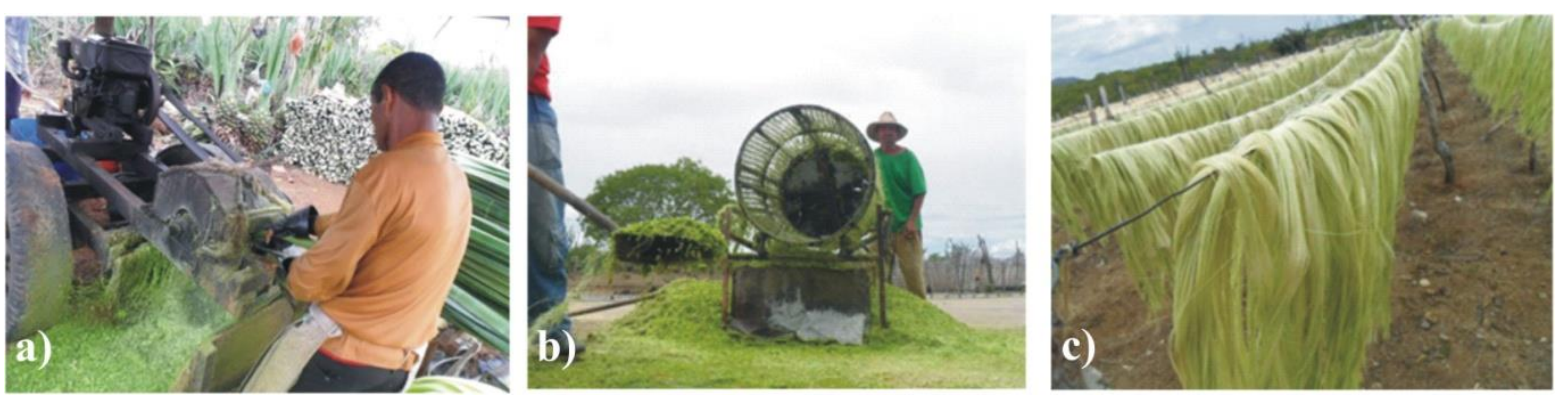

FIGURE 1. Production process of sisal fiber: a) Extraction of sisal fiber; b) Drying of the fiber; c) Separation of the sisal residue

Agricultural residue applications as reinforcement of composites has been observed in the last years because it has physical and mechanical properties close to natural fibers (KARADE, 2010; CARNEIRO et al., 2010; RAUT et al., 2011). Despite the recognized chemical incompatibility between the fiber and conventional cement matrix, in cement-based composites, the use of pozzolanic additives have avoided the chemical attack on the natural fiber and ensuring their durability (LIMA \& TOLEDO FILHO, 2008). However, fiber residues are hydrophilic resulting in poor adhesion at the fiber-matrix interface and loss of strength of the composite is observed. Aiming to enhance fiber behavior with cement-based matrices, chemical treatments have been studied but in many situations it can affect unfavorably the sisal tensile strength (LOPES et al., 2003). An alternative is the treatment of the fibers by the application of wetting-drying cycles. These cycles promotes a lower volumetric expansion of natural pulps and it can be used to improve the durability of mortars reinforced with cellulosic fibers (CLARAMUNT et al., 2010). This phenomenon is called "hornification' and results in a rearrangement of the polysaccharides cellulose chains in a tighter way with the removal of water during the drying process. Thereby the micro-fibrils are joined with each other in the dry state as a result of the larger packing (DINIZ et al., 2004). The fiber capillary voids are gradually closed with the cycles and can no longer be completely reopened with re-humidification. 
The aim of this study was to investigate the possibility of using sisal fiber residues, refugo and field bush, as reinforcement of cement-based composites. To improve the compatibility with the cement matrix the fiber was modified by drying and rewetting cycles and the fiber-matrix bond and mechanical properties of sisal fiber residue reinforced cement-based composites were investigated

\section{MATERIALS AND METHODS}

Matrix mix design was 1:0.5:0.4 (binder: sand: water / cement ratio) by weight. A binder composed of $50 \%$ of Portland cement CP V (ASTM Type III) with specific gravity of $3.1 \mathrm{~g} / \mathrm{cm}^{-3}$,

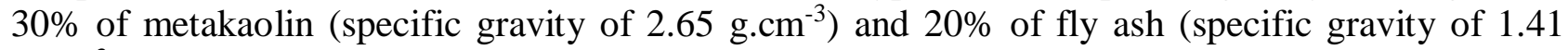
g. $\mathrm{cm}^{-3}$ ) was used. This ratio of fly ash and metakaolin aims to guarantee the durability of the fiber, as shown in the previous research (LIMA \& TOLEDO FILHO, 2008; MELO FILHO, 2005). The sand used was processed to obtain a maximum diameter of $1.18 \mathrm{~mm}$ and fineness of $1.79 \mathrm{~mm}$. The particle distribution curves of materials are shown in Figure 2.

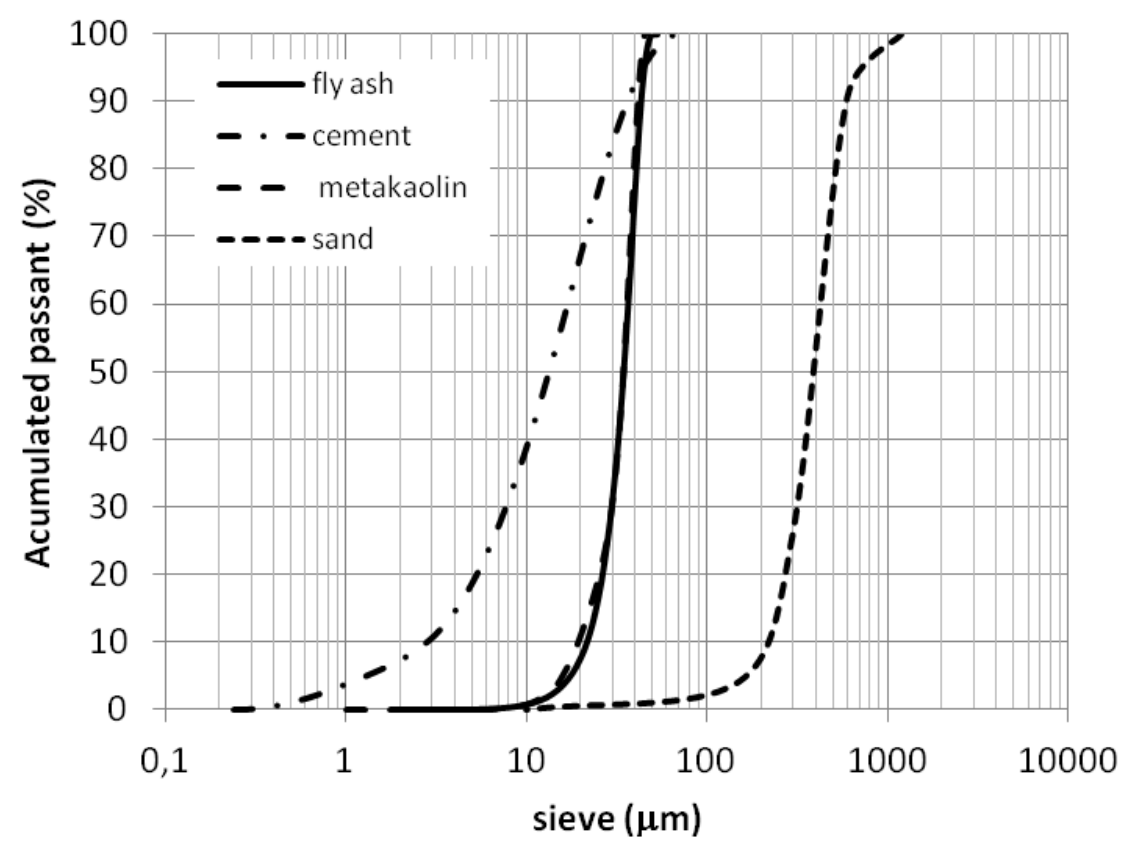

FIGURE 2. Granulometric analysis of materials.

Refugo and field bush were collected in the city of Valente, state of Bahia - Brazil. Sisal fiber was also used as reference. Initially, the fibers were washed in hot water $\left(50{ }^{\circ} \mathrm{C}\right)$ to remove surface residues, such as mucilages, from the extraction process. Fiber treatment, conduced according to Ferreira et al. (2012), consisted in immersing the fibers in water $\left(\mathrm{T} \sim 23{ }^{\circ} \mathrm{C}\right)$ and their removal after saturation $(3 \mathrm{~h})$ for drying in a furnace at a temperature of $80^{\circ} \mathrm{C}(16$ hours $)$. This procedure was repeated for 10 and 20 times.

The apparent diameter of the fibers was measured by an optical microscope (Quimis Q711FT Model; Motic Image Plus 2.0 software) at 10X magnification. For each fiber, the average of the three measurements of the width at three regions of the fiber was taken and considered as the apparent diameter of the fiber, whose cross section was admitted as circular. This method has been adopted by other researchers (KIM \& NETRAVALI, 2005; TOMCZAK et al, 2007) despite the knowledge that the cross section of vegetable fibers are irregular and vary along the length of the fiber. Also because the use of more sophisticated methods (SILVA et al, 2008) have not led to a reduction of variability in the determination of the cross-sectional area. Consequently, the calculation of mechanical properties associated with the cross section of the fiber, such as tensile strength, have high coefficient of variation and many samples need to be used in the test. 
The surface structure of the sisal fiber and sisal residues was investigated in order aiming to determine possible differences among the various fiber types and assess the treatment effectiveness using a scanning electron microscope (JEOL JSM-6460).

The Fourier transform infrared (FTIR) spectroscopy was used to analyze the composition change of the treated sisal residue. FTIR spectrum were obtained for both sisal and residue fibers using a Perkin Elmer spectrometer.

The tensile tests were performed in a TA.XT Plus Texture Analyzer with a load cell of $500 \mathrm{~N}$. Figure $3 \mathrm{a}$ presents the test setup. The tests were performed with 20 fibers using a displacement rate of $0.03 \mathrm{~mm} . \mathrm{s}^{-1}$. The fibers with a gage length of $50 \mathrm{~mm}$ were glued to a paper template for better alignment in the machine and for a better gripping with the upper and lower jaws. The tensile strength was obtained at rupture load.
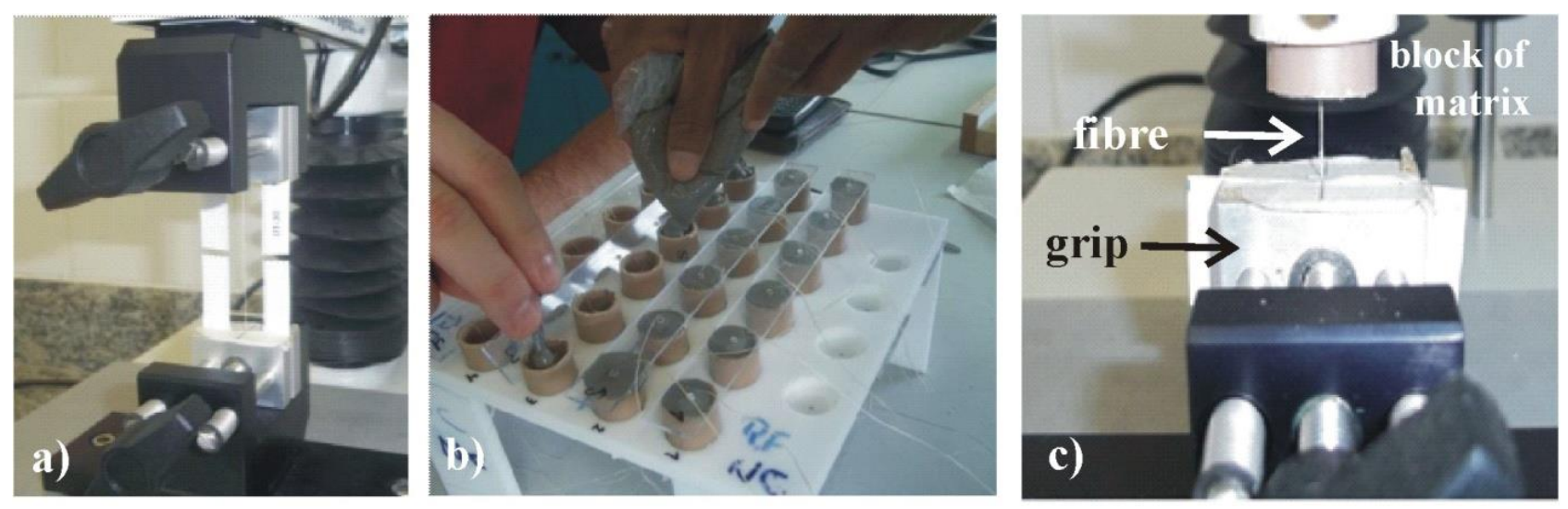

FIGURE 3. Test Methods: a) Tensile test setup; b) Pull-out mold filling; b) Pull-out test setup

To mold the pull-out specimens a special formwork of PVC tubes was developed (Figure $3 \mathrm{~b}$ and 3c). Twelve specimens were cast with an embedment length of $20 \mathrm{~mm}$. After 24 hours, the specimens were cured in a humid chamber at $23 \pm 2 \mathrm{C}$ and relative humidity of $95 \%$ for 14 days before the pull-out test. The tests were performed in a TA.XT Plus Texture Analyzer with a load cell of $500 \mathrm{~N}$ and a displacement rate of $0.02 \mathrm{~mm} . \mathrm{s}^{-1}$. The average interfacial strength was calculated using Eq. (1):

$$
\tau=\mathrm{F} /(\pi . \mathrm{d} . l)
$$

where:

$\mathrm{F}=$ the maximum load measured,

$\mathrm{d}=$ the fiber diameter, and

$l=$ fiber embedded length.

The matrix used in this study showed a flow table spread value of $345 \mathrm{~mm}$ according to the Brazilian Standards NBR 13276 (ABNT, 2005). The mixtures were produced using a mixer with a capacity of $5 \mathrm{dm}^{3}$. All dry components were homogenized in the mixer. Water was added and mixed for $2 \mathrm{~min}$ at low speed $(125 \mathrm{rpm})$. After this, the process was stopped during $30 \mathrm{~s}$ to remove the material retained in the mixer. Then the mixing procedure continued for $2 \mathrm{~min}$ at medium speed $(220 \mathrm{rpm})$ and finally for a further $5 \mathrm{~min}$ at the fastest speed $(450 \mathrm{rpm})$. After the $2 \mathrm{~min}$ mixing at medium speed, the sisal fibers were added and mixed at the medium speed for $4 \mathrm{~min}$. Chopped treated and untreated sisal fibers with $25 \mathrm{~mm}$ length were used in a $2 \%$ volume fraction.

The flexural strength of the composites was determined on prisms 40 x 40 x $160 \mathrm{~mm}^{3}$, according to NBR 13279 (ABNT, 2005), after 28 days of cure, under a three point bending 
configuration. A $1000 \mathrm{kN}$ testing machine was used, with a $50 \mathrm{kN}$ load cell, at a rate of axial loading of $500 \mathrm{~N} \cdot \mathrm{s}^{-1}$.

The flexural behavior was evaluated in prismatic specimens of dimensions $5 \times 40 \times 160 \mathrm{~mm}^{3}$. The specimens were tested on a $100 \mathrm{kN}$ testing machine at a rate of an axial displacement of 0.2 mm.min ${ }^{-1}$. The load and mid-span displacements, using a LVDT, were continuously recorded using a data acquisition system. The toughness index $\left(\mathrm{F}_{\mathrm{T}}\right)$ was determined using the formula given by Eq. (2):

$$
\mathrm{F}_{\mathrm{T}}=(\mathrm{n} \cdot \mathrm{T}) /\left(\mathrm{b} \cdot \mathrm{d}^{2}\right)
$$

where,

$\mathrm{n}=150$

$\mathrm{T}=$ the energy required to deflect the beam to a midpoint deflection of $\mathrm{L} / 150$ of its free span (L), which in this study corresponds to a deflection of $0.73 \mathrm{~mm}$;

$\mathrm{d}$ and $\mathrm{b}=$ the depth and width of the specimen, respectively.

$\mathrm{T}$ value was obtained by the integration of the area below the load vs. the deflection curve at the corresponding deflection.

\section{RESULTS AND DISCUSSION}

\section{a) sisal fiber residues properties}

Figure 4 shows the SEM images of the sisal fiber, refugo and field bush. The lateral structure of the different types of fiber is similar. However, in sisal residues, holes and rupture of the lateral wall of the fiber can be observed. Different cross-sections were also identified. The sisal fiber and refugo evaluated show a horse-shoe shape while the field bush shows a twisted arch shape.

Side-by-side box-and-whiskers plots of the three fiber measures are shown in Figure 4. The length of the box represents the middle $50 \%$ of the distribution, i.e. the top is the 75 th percentile and the bottom the 25th percentile. The little box within the box is the median level. The extent of the lines (whiskers) above and below the boxes represents the remaining parts of the distribution. Examination of Figure 5 reveals that field bush values are more narrowly distributed. The widest distribution of values occurs with the sisal fiber. Sisal and refuge show an average apparent diameter of about $280 \mu \mathrm{m}$ and $267 \mu \mathrm{m}$, respectively. The field bush, however, presents a apparent diameter of about $181 \mu \mathrm{m}$. This difference is associated with the localization of the fiber within the sisal leaf. The sisal plant leaf is a functionally graded composite structure which is reinforced by three types of fibers: structural, arch, and xylem fibers. The first occurs in the periphery of the leaf providing resistance to tensile loads while the others present secondary reinforcement, occurring in the middle of the leaf, as well as, a path for nutrients (SILVA \& CHAWLA, 2008). 

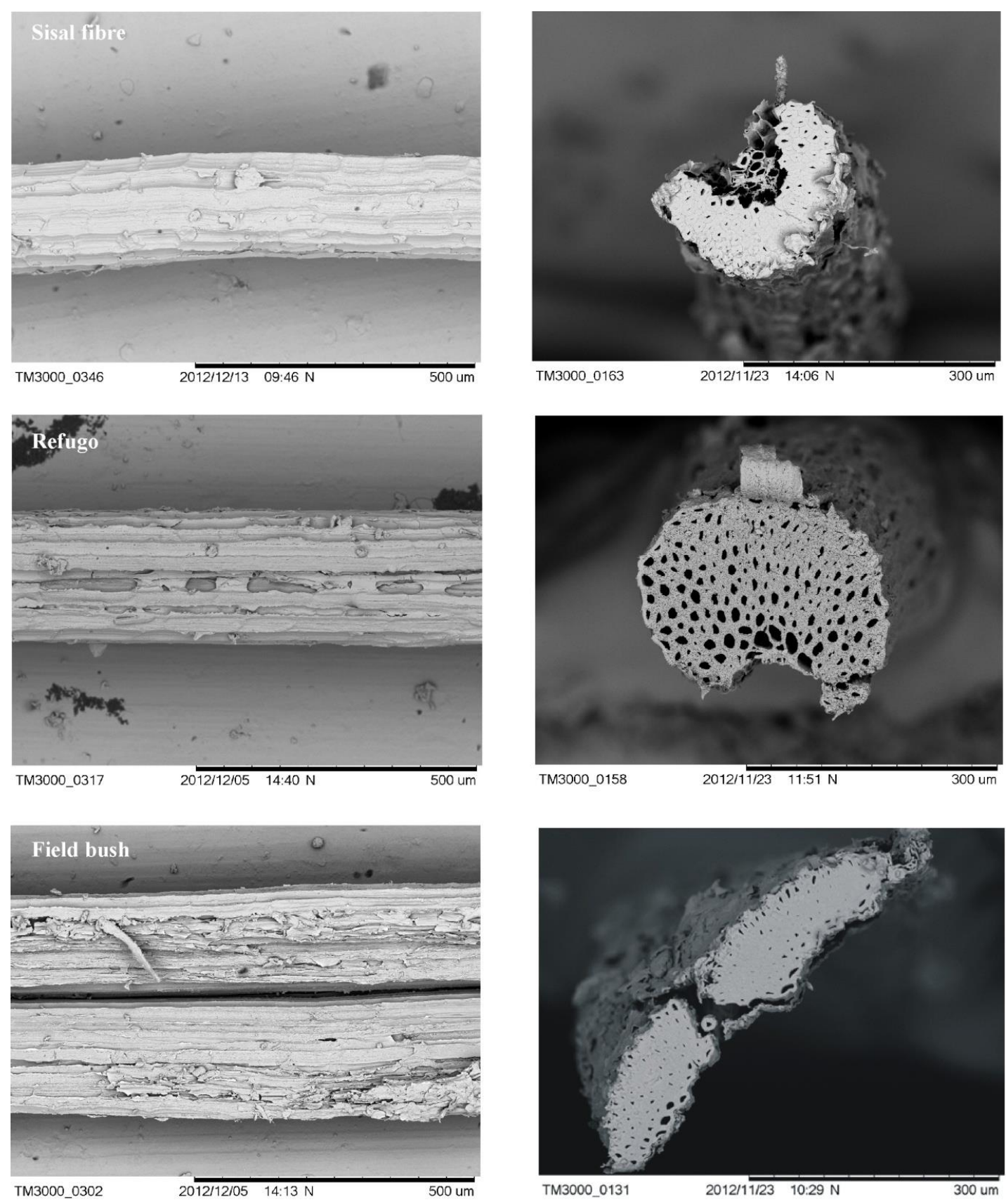

a) lateral structure

b) cross sectional geometry

FIGURE 4. Morphology of sisal fiber and residues.

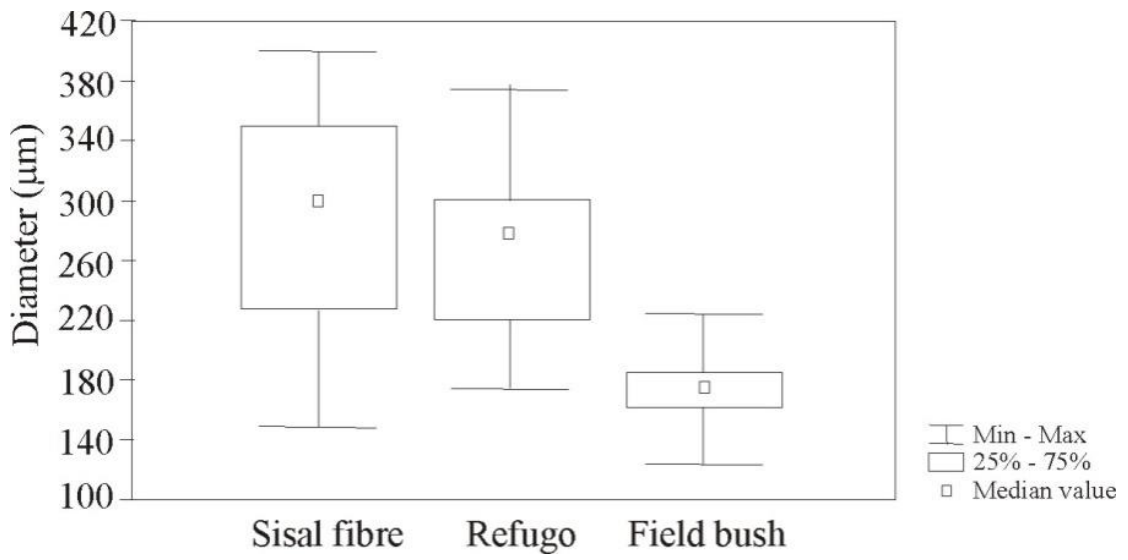

FIGURE 5. Box and whisker plot for apparent diameter of fibers. 
Figure 6 shows the effect of the treatment on fiber structure. Sisal fiber shows no significant change after 10 cycles and a little deterioration is observed in the sidewall after 20 cycles. For refugo, the presence of more imperfections and transversal cracks on its surface, after 10 cycles, and rupture of fiber cells, after 20 cycles are noted. Field bush fibers show the most important deterioration due to wet-dry cycles. After 20 cycles a total separation of fiber cells indicating the dissolution of middle lamellae, which are built up of hemicellulose, lignin and pectin is observed.

Another effect of wet-dry cycles on natural fibers is the stiffening of the polymer structure that takes place in lignocellulosic materials upon drying or water removal. SEM images of fiber cells of sisal fiber are shown in Figure 7. After 10 cycles a reduction of volume of lumen and the presence of micro-cracks across fiber cells are noted. A reduction of the medium diameter of fiber, also reported by Ferreira et al. (2012) is observed after treatment, as shown in Table 1.
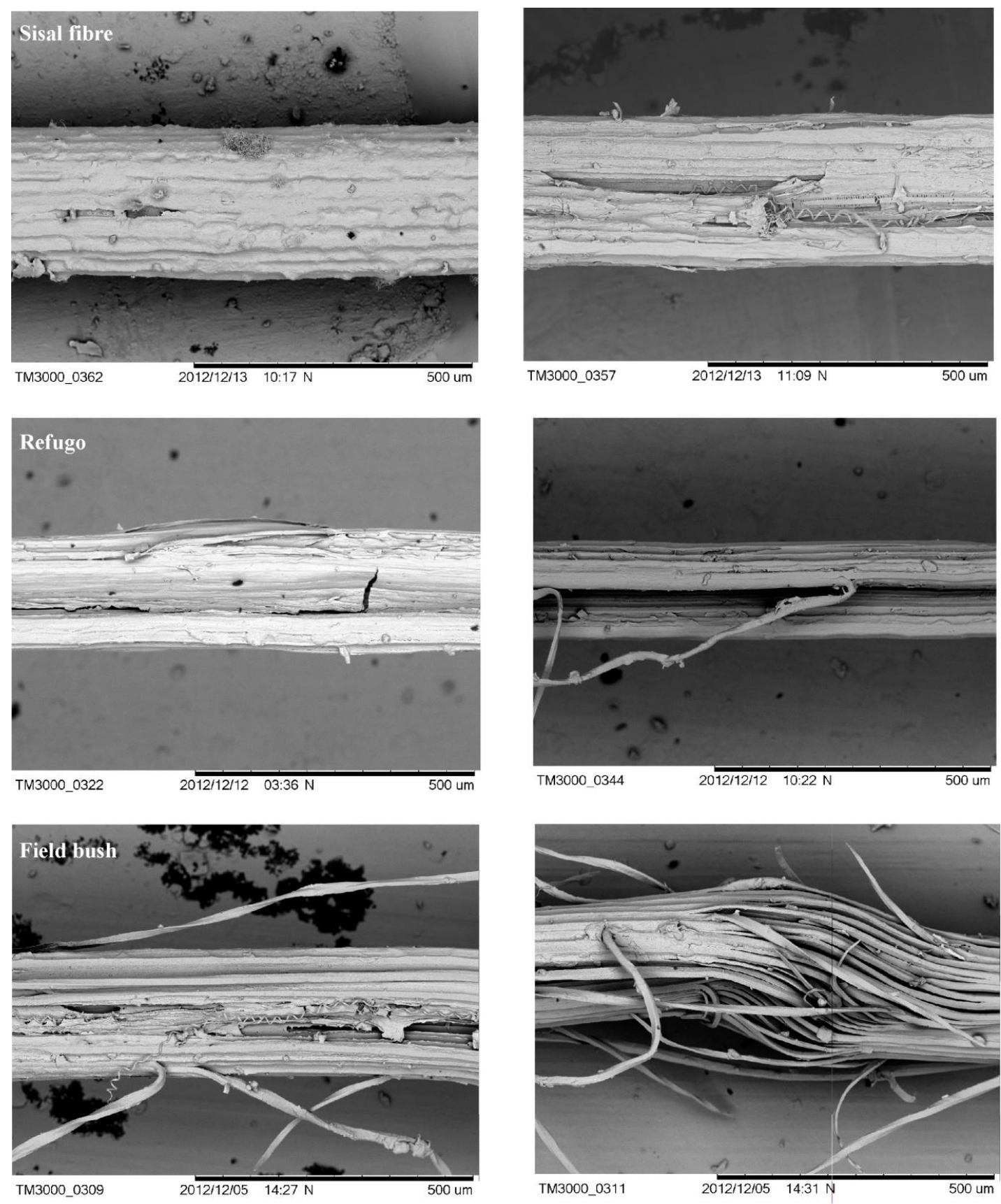

a) 10 cycles

b) 20 cycles

FIGURE 6. Effect of treatment on fiber and residue structures. 


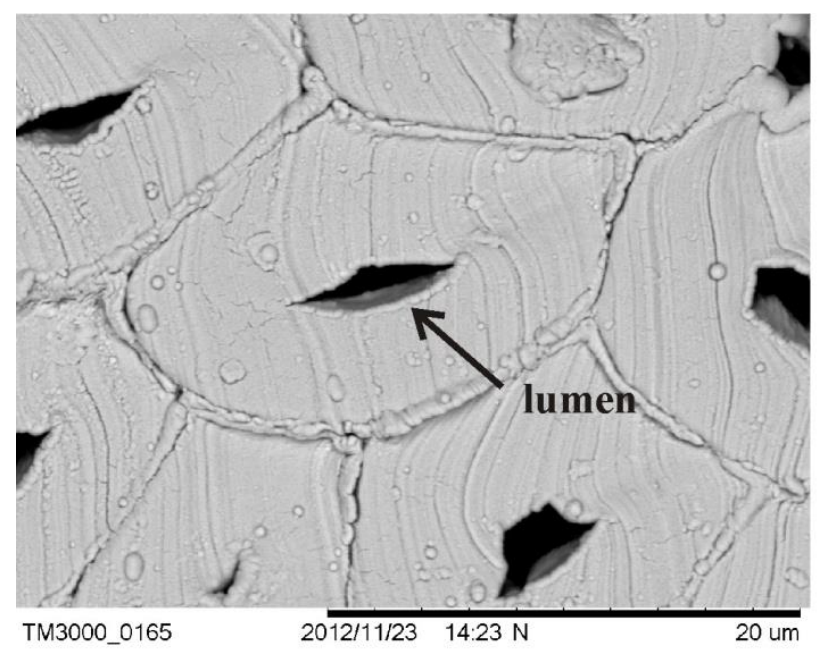

a) Natural

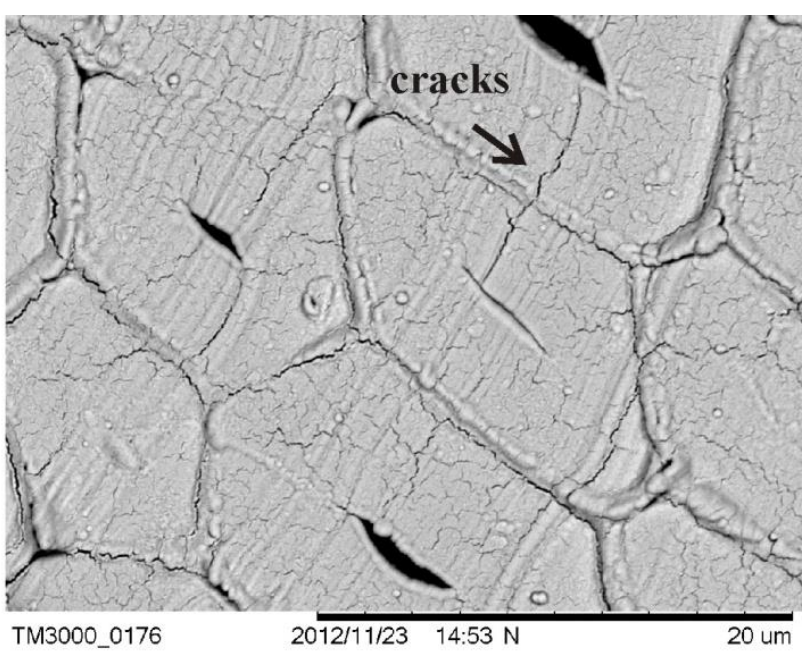

b) 10 cycles

FIGURE 7. Effect of treatment on fiber cell.

Figures 8-10 shows the FTIR spectrum of untreated and treated sisal residues and sisal fiber. The peak at $1733.8 \mathrm{~cm}^{-1}$ is assigned to $\mathrm{C}=\mathrm{O}$ unconjugated stretching of carboxylic acid or ester of the hemicelluloses and the peak at $1239.1 \mathrm{~cm}^{-1}$ is assigned to $\mathrm{C}-\mathrm{O}$ stretching vibration of acyl group present in the lignin (HERRERA-FRANCO \& VALADEZ-GONZÁLEZ, 2005; KIM \& NETRAVALI, 2010). The broad peak in the range of 3300-3500 $\mathrm{cm}^{-1}$ and a peak at $1630 \mathrm{~cm}^{-1}$ are due to the characteristics axial vibration of hydroxyl group of cellulose (preferably from 2,3 and 6 carbon of glucose). The peak at around $1080 \mathrm{~cm}^{-1}$ is due to the associated hydrogen group (MOHAN \& KENNY, 2012). For the evaluation of all spectra is possible to verify that there was no disappearance of any of the major peaks. This indicates that the treatment applied does not alter the chemical structure of the fibers and sisal residues.

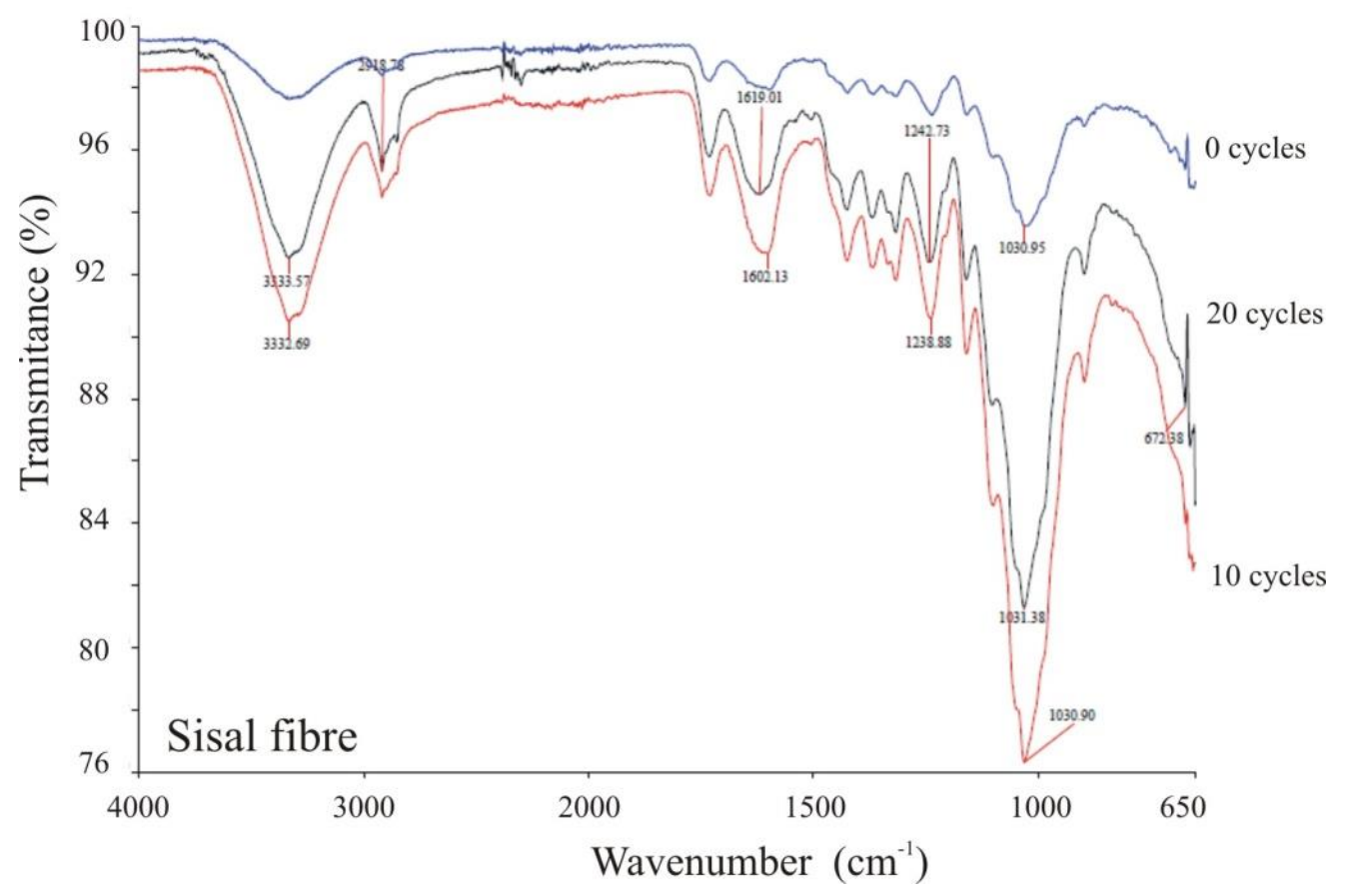

FIGURE 8. Fourier transform infrared (FTIR) spectrum for treated and untreated sisal fiber. 


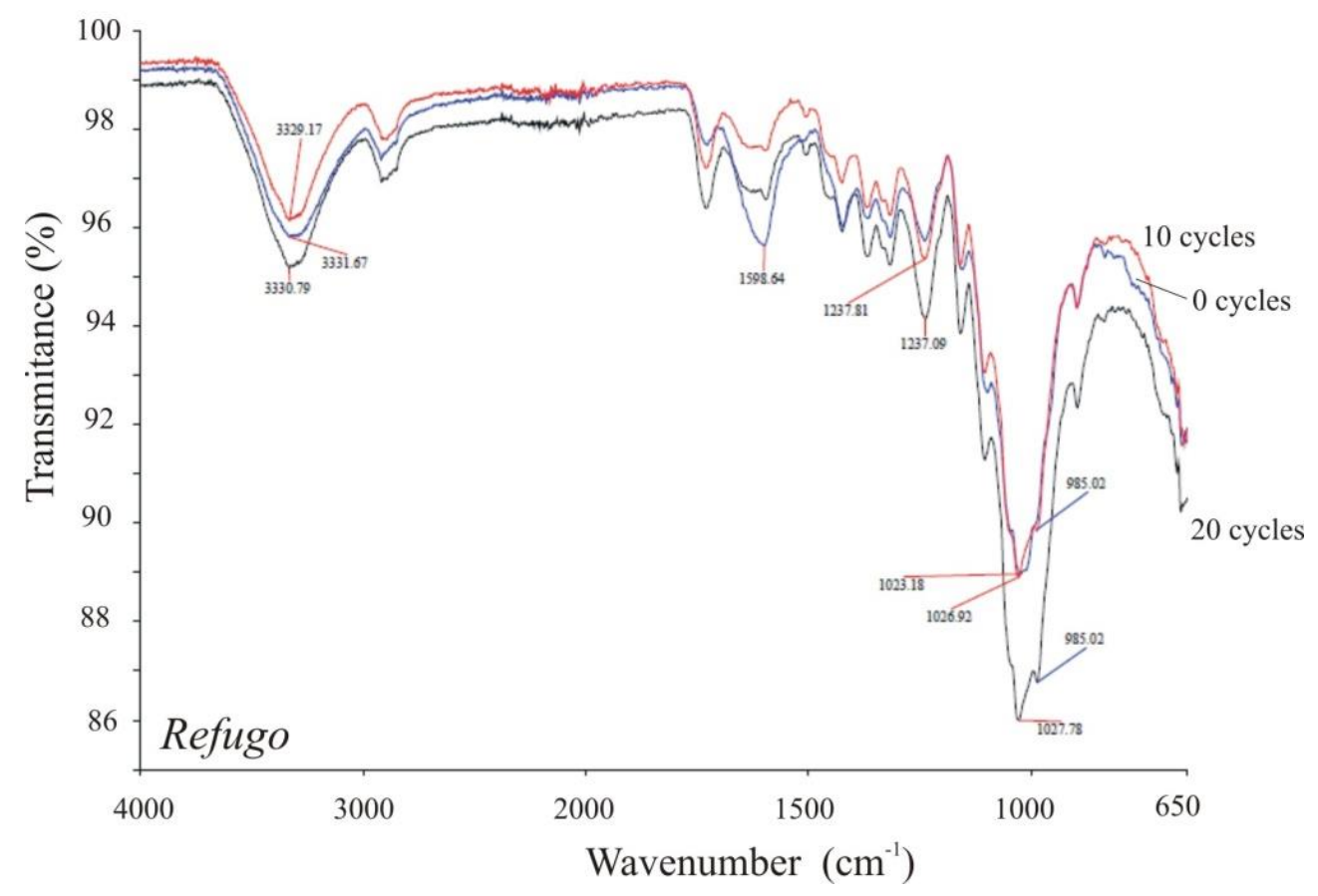

FIGURE 9. Fourier transform infrared (FTIR) spectrum for treated and untreated refugo.

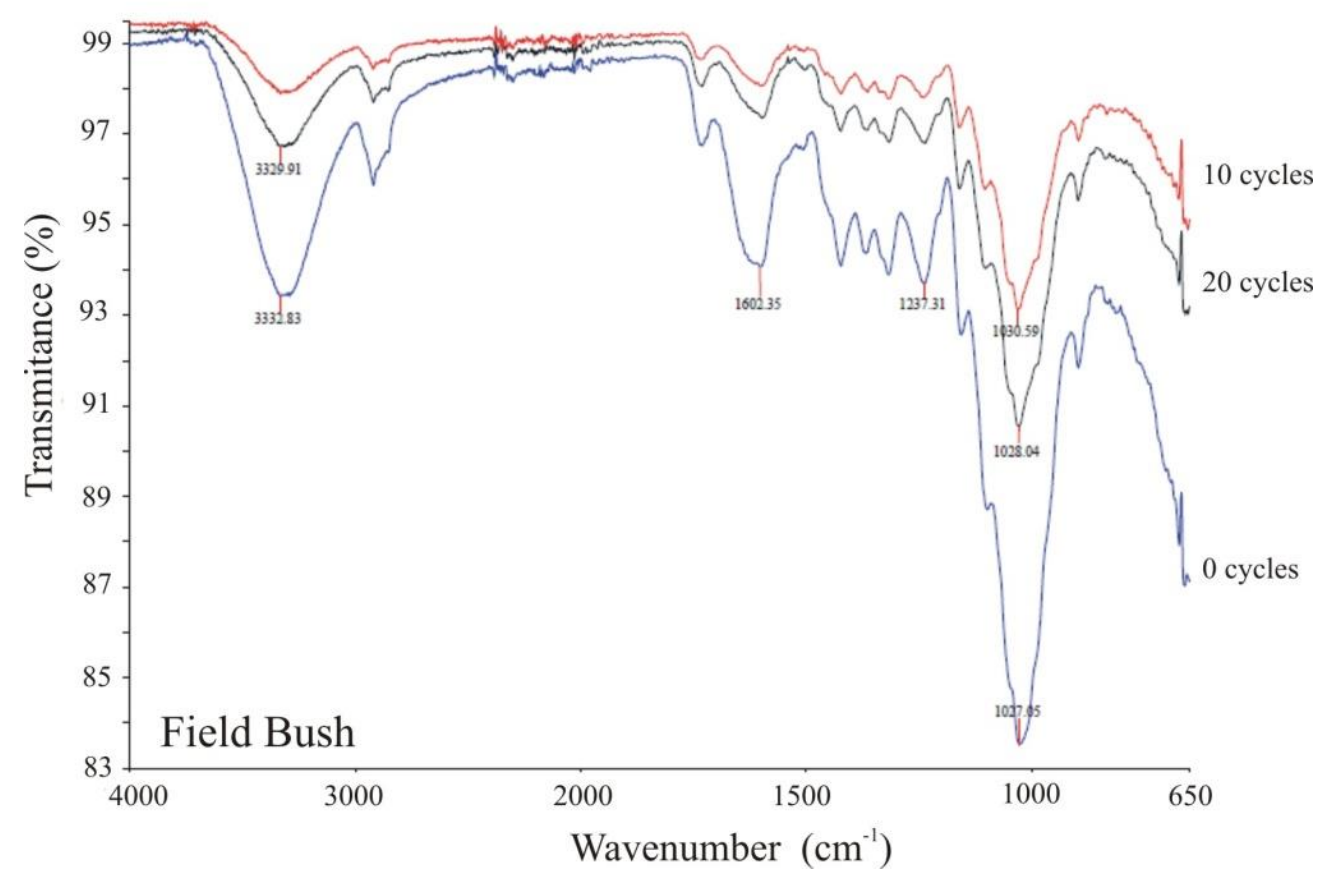

FIGURE 10. Fourier transform infrared (FTIR) spectrum for treated and untreated field bush.

In order to evaluate the effect of the treatment on mechanical properties of fiber sisal and residues, tensile tests were performed. The calculated tensile strengths using equivalent fiber diameter are also shown in Table 1. Comparing the different types of sisal-based materials used, it is found that tensile strength of field bush fibers untreated is similar to those of sisal fiber and that refugo fiber show a reduction of $25 \%$ in this property. It can be seen that the treatment with 10 cycles had not influence on fiber strength. However, for treatment with 20 cycles a reduction up to $36 \%$ in tensile strength due to modification of fiber structure is observed. 
TABLE 1. Median value and coefficient of variation (in \%) of diameter and tensile strength of fiber.

\begin{tabular}{lcccccc}
\hline & \multicolumn{2}{c}{ Sisal fiber } & \multicolumn{2}{c}{ Refugo } & \multicolumn{2}{c}{ Field bush } \\
\cline { 2 - 7 } Cycles & $\begin{array}{c}\text { Apparent diameter } \\
(\mu \mathrm{m})\end{array}$ & $\begin{array}{c}\text { Tensile } \\
\text { strength } \\
(\mathrm{MPa})\end{array}$ & $\begin{array}{c}\text { Apparent } \\
\text { diameter } \\
(\mu \mathrm{m})\end{array}$ & $\begin{array}{c}\text { Tensile } \\
\text { strength } \\
(\mathrm{MPa})\end{array}$ & $\begin{array}{c}\text { Apparent } \\
\text { diameter }(\mu \mathrm{m})\end{array}$ & $\begin{array}{c}\text { Tensile } \\
\text { strength } \\
(\mathrm{MPa})\end{array}$ \\
\hline 0 & $280(27)$ & $363^{\mathrm{a}, \mathrm{x}}(27)$ & $267(20)$ & $271^{\mathrm{b},}(36)$ & $200(12)$ & $356^{\mathrm{c}, \mathrm{x}}(22)$ \\
10 & $244(27)$ & $353^{\mathrm{a}, \mathrm{y}}(27)$ & $246(32)$ & $272^{\mathrm{b}, \mathrm{y}}(35)$ & $194(14)$ & $322^{\mathrm{c}, \mathrm{y}}(18)$ \\
20 & $220(20)$ & $2^{\mathrm{z}}\left(24^{\mathrm{z}}(24)\right.$ & $245(22)$ & $224^{\mathrm{z}}(29)$ & $196(15)$ & $257^{\mathrm{z}}(33)$ \\
\hline
\end{tabular}

*Means followed by equal letters $(\mathrm{a}, \mathrm{b}$ or $\mathrm{c}$ ) within each column are significantly equal and means followed by equal letters (x, y or $\mathrm{z})$ within each line are significantly equal according to the Tukey test $(\mathrm{p}<0.05)$.

\section{b) Pull-out behavior and flexural properties of composites}

The pull-out test is important by itself as it simulates the fiber bridging-pull-out phenomenon during the fracture process of sisal cement composites. Results of untreated and treated fiber pullout test using cement mortar as the matrix are presented in a force-slip diagram in Figure 11. Sisal based-materials submitted to 20 cycles of this treatment was not used due to a higher reduction of tensile strength. All the studied fibers were entirely pulled-out from the cement matrix without any breakage.

Observing the load-slip curves for all fibers (Figure 11) and to make a comparison with schematic load-slip behavior (BARTOS, 1981) it is possible to verify that the treatment improved the interfacial bond between fiber and matrix, mainly in the elastic and de-bonding stages. In the frictional stage the fiber treatment is not effective.

For the untreated fiber, the interfacial transition zone between cement matrix and natural fibers is porous and cracked (SAVASTANO JR \& AGOPYAN, 1999) due to the poor interface that results in the incompatibility between the hydrophilic fiber and the matrix (VALADEZGONZALEZ et al., 1999). During the drying of the composite, the fiber has a significant shrinkage and cracks develop in the interfacial zone, even before the application of loads. The de-bonding is then the result of the propagation of the fracture in interface.

In treated fiber, the hornification process results in the reduction of lumen and consequently of water absorption capacity. Thus, the preexisting cracks due shrinkage of the matrix are smaller, which increases the adhesion between the fiber and the matrix.

The average interfacial strength calculated using Eq.1 for the pull-out test is presented in Table 2. It can be observed that the fiber treatment increased the bond strength, regardless of the type of the fiber. This increase was about 55\%, $47 \%$ and $19 \%$ for sisal fiber, refugo and field bush, respectively.

The flexural strength of cement-based composites reinforced with sisal fiber and sisal residues are shown in Table 2. The addition of untreated sisal fiber, refugo or field bush increases the flexural strength of about $24 \%, 65 \%$ and $16 \%$, compared to the matrix, respectively. For flexural strength, the fiber treatment provokes a negative effect on composite reinforced with refugo or field bush with reductions of 23.1 and $6.3 \%$, respectively, compared to composites reinforced with untreated fibers. However, the toughness has improved for refugo reinforced composites after treatment of this fiber. 

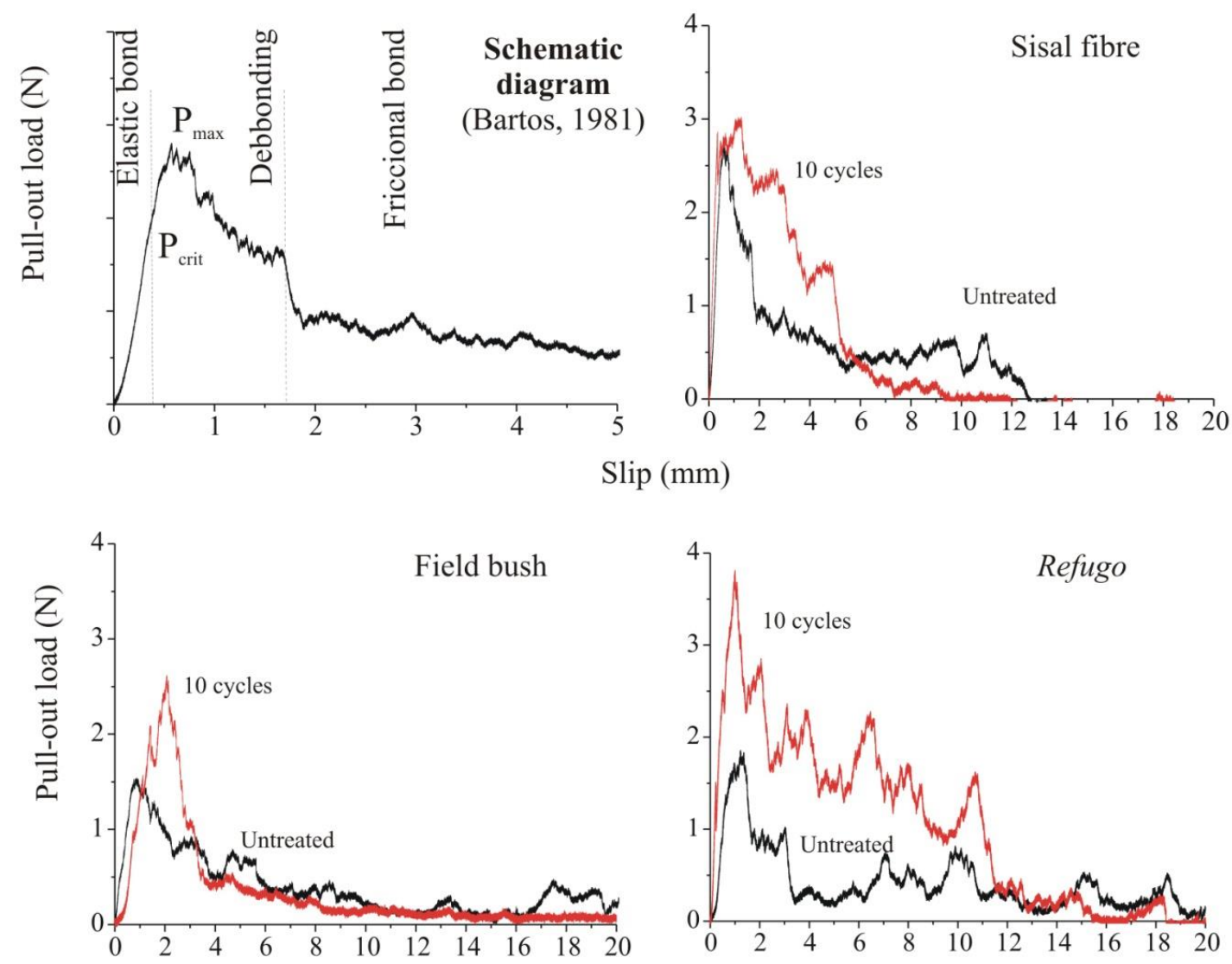

Slip $(\mathrm{mm})$

FIGURE 11. Effect of the fiber treatment on pull-out behavior

Typical three-point bending curves are shown in Figure 12. The same behavior on the flexural test was observed for all mixtures: an elastic linear behavior is observed up to the point where the matrix cracks and the post cracking range was characterized by a single cracking formation and the pull-out of fibers. Composites show a sudden drop loading after the first cracking and then keep the load constant until fibers were pulled out of the matrix in the cracked region. For treated refugo reinforced composite an increase of the load after sudden failure higher than for sisal fiber reinforced composite is observed. The subsequent increase in load indicates that the fibers, at this stage of deflection, were still effective in redistributing the stresses into the matrix. This is a result of better adhesion between the fiber and the matrix which transfers the load between the cracks.

Compared with untreated sisal fiber reinforced composites, an increment of toughness of refugo reinforced composites is verified in Figure 12. For the reinforced composite with field bush the modification of fiber after treatment does not result in increment of toughness and the loaddisplacement behavior was maintained.

TABLE 2. Average value and coefficient of variation (by \%) of composite mechanical properties.

\begin{tabular}{lcccc}
\hline \multicolumn{5}{c}{ Average interfacial strength (MPa) } \\
\hline Cycles & Sisal fiber & \multicolumn{2}{c}{ Refugo } & Field bush \\
\hline 0 & $0.18(16)$ & $0.17(39)$ & $0.16(35)$ \\
10 & $0.28(35)$ & \multicolumn{2}{c}{$0.25(37)$} & $0.19(38)$ \\
\hline \multicolumn{5}{c}{ Flexural strength of composite (MPa) } \\
\hline Cycles & Matrix & Sisal fiber & Refugo & Field bush \\
\hline 0 & $3.70(2)$ & $4.60(8)$ & $6.11(39)$ & $4.28(7)$ \\
10 & - & $5.00(17)$ & $4.65(10)$ & $4.00(8)$ \\
\hline
\end{tabular}



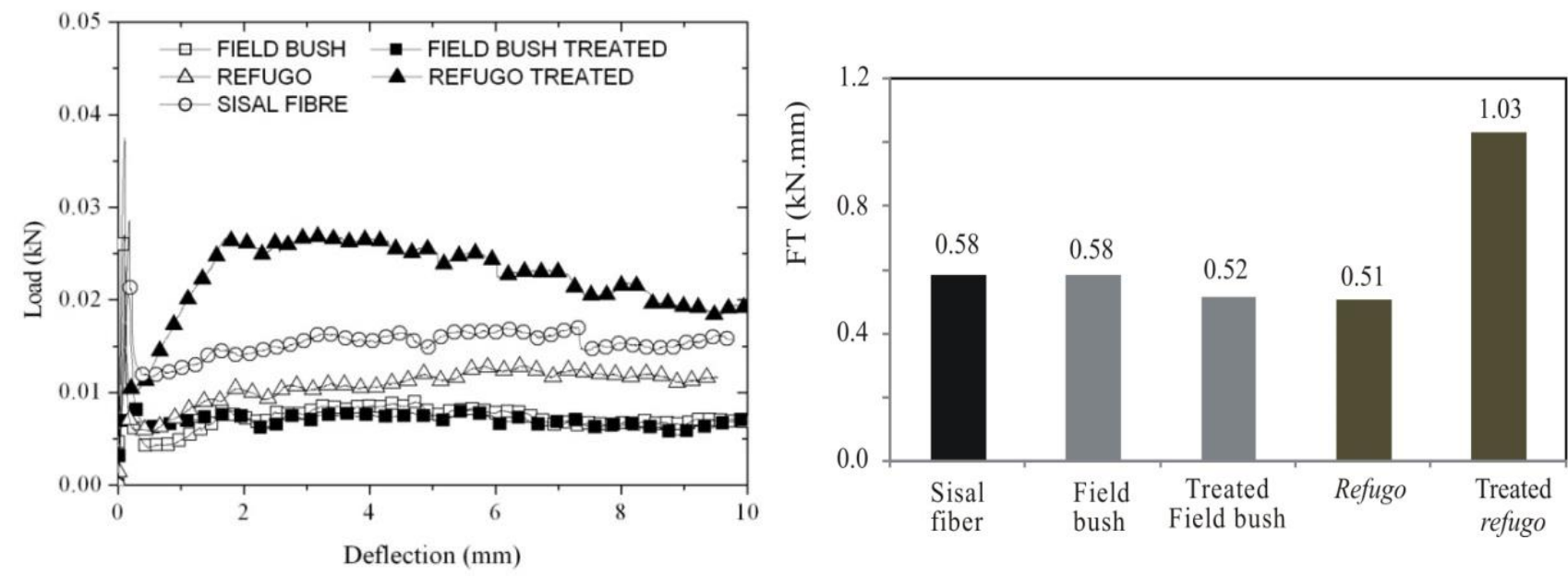

FIGURE 12. Effect of fiber treatment on three-point bending response of composites.

\section{CONCLUSIONS}

This study demonstrated the potential of the use of sisal residues as reinforcement of cementbased composites. Based on the results the following conclusions can be drawn.

The sisal fibers residues, refugo and field bush, have a smaller diameter and a lower mechanical strength than the sisal fibers. Unlike sisal fiber, in sisal residues, holes and rupture of the lateral wall of the fiber can be observed.

The treatment of fibers and residues, with 10 and 20 wet-dry cycles, demonstrates that the application of 10 cycles had a minor influence on the strength and structure of the fiber. Thus, for 20 cycles an important reduction of strength is observed.

SEM micrographs of the fiber surface indicate a reduction of volume of lumen and the presence of micro-cracks across the fiber cells and the sidewall after treatment. Field bush fibers showed the most important deterioration due to wet-dry cycles with total separation of fiber cells indicating a possible dissolution of middle lamellae. However, the FTIR analysis indicates that the treatment applied does not alter the chemical structure of the fibers and sisal residues.

The interfacial shear strength between treated fibers and cement-based matrix was significantly superior to that of untreated ones. The wet-dry cycles reduces the water absorption capacity and dimensional variation of the fibers, which results in reduced amount of cracks in the interfacial zone before the application of loads.

The post peak behavior and toughness of cement-based composite reinforced with refugo submitted to 10 cycles of treatment increased due to the improvement of the interface bond between the fiber and matrix and resulted in a composite with better flexural behavior than untreated sisal fiber reinforced composite.

\section{ACKNOWLEDGEMENTS}

The authors thank the Research Foundation of the State of Bahia (FAPESB), the National Council for Scientific and Technological Development (CNPq: 558633/2010-2) for their support and the Bioactive Natural Products Lab. (LAPRON/UEFS) for their support in the achievement of FTIR tests.

\section{REFERENCES}

ABNT - Associação Brasileira de Normas Técnicas. NBR 13276 Argamassa para assentamento e revestimento de paredes e tetos - Preparo da mistura e determinação do índice de consistência, Rio de Janeiro, 2005. 3p.

ABNT - Associação Brasileira de Normas Técnicas. NBR 13279 Argamassa para assentamento e revestimento de paredes e tetos - Determinação da resistência à tração na flexão e à compressão, Rio de Janeiro, 2005. 9 p., 
ALMEIDA, E. A.; PASSINI, R. Thermal comfort in reduced models of broilers' houses, under different types of roofing materials. Engenharia Agrícola, Jaboticabal, v. 33, n. 1, p. 19-27, 2013.

BARTOS, P. Review paper: Bond in fiber reinforced cements and concretes. International Journal of Cement Composite and Lightweight Concrete, Harlow, v. 3, p. 159-77, 1981.

BILBA, K.; ARSENE, M. A. Silane treatment of bagasse fiber for reinforcement of cementitious composites. Composites. Part A, Kidlinton, v. 39, p. 1488-95, 2008.

CARNEIRO, V. L.; LIMA, P. R. L.; LEITE, M. B. Avaliação das propriedades físicas e mecânicas de pastas compósitas auto-compactáveis reforçadas com fibras curtas de coco. In: CONGRESSO IBÉRICO SOBRE BETÃO AUTO-COMPACTÁ VEL, 2010, Guimarães. Anais... CD ROM.

CLARAMUNT, J.; ARDANUY, M.; GARCIA-HORTAL, J.A., Effect of drying and rewetting cycles on the structure and physicochemical characteristics of softwood fibers for reinforcement of cementitious composites. Carbohydrate Polymers, Barking, v. 79, p. 200-205, 2010.

DINIZ, J.; GIL, M.; CASTRO, J. Hornification-its origin and interpretation in wood pulps. Wood Science and Technology, New York, v. 37, p. 489-494, 2004.

FARIAS FILHO, J.; TOLEDO FILHO, R. D.; LIMA, P. R. L. Efeito da argila calcinada sobre a durabilidade de argamassas reforçadas com fibras curtas de sisal. Revista Brasileira de Engenharia Agrícola e Ambiental, Campina Grande, v. 14, n. 10, p. 1109-14, 2010.

FERREIRA, S.; LIMA, P. R. L.; SILVA, F.; TOLEDO FILHO, R. D. Effect of sisal fiber hornification on the adhesion with portland cement matrices. Materia, Rio de Janeiro, v.17, p.1024$1034,2012$.

FIORELLI, J.; SCHMIDT, R.; KAWABATA, C. Y.; OLIVEIRA, C. E. L.; SAVASTANO JÚNIOR, H.; ROSSIGNOLO, J. A. Eficiência térmica de telhas onduladas de fibrocimento aplicadas em abrigos individuais para bezerros expostos ao sol e à sombra. Ciência Rural, Santa Maria, v.42, n.1, p.64-7, 2012.

GHAFFARIANHOSEINI. A.; DAHLANA, N. D.; BERARDI, U.; GHAFFARIANHOSEINI, A.; MAKAREMI, N.; GHAFFARIANHOSEINI, M. Sustainable energy performances of green buildings: A review of current theories, implementations and challenges. Renewable and Sustainable Energy Reviews, v. 25, p.1-17, 2013.

HERRERA-FRANCO, P. J.; VALADEZ-GONZALEZ, A. A study of the mechanical properties of short natural-fiber reinforced composites. Composite. Part B, Kidlinton, v. 36, p.597-608, 2005.

KARADE, S. R. Cement-bonded composites from lignocellulosic residues. Construction and Building Materials, Guildford, v.24, p.1323-30, 2010.

KIM, J. T.; NETRAVALI, A. N. A study of the mechanical properties of short natural-fiber reinforced composites. Composites: Part B, Kidliton, v. 36, p.597-608, 2005.

LIMA, P. R. L.; TOLEDO FILHO, R. D. Use of metakaolin to improve the durability of sisal fibercement-based composites. Ambiente Construído, v.8, p.7-19, 2008.

LOPES, F. F. M.; ARAÚJO, G. T.; NASCIMENTO, J. W. B.; GADELHA, T. S.; SILVA, V. R. Estudo dos efeitos da acetilação em fibras de sisal. Revista Brasileira de Engenharia Agricola $e$ Ambiental, Campina Grande, v.14, n.7, p. 783-8, 2010.

MELO FILHO, J. A. Desenvolvimento e Caracterização de Laminados Cimentíceos Reforçados com Fibras Longas de Sisal. 2005, 114f. Dissertação (Mestrado em Engenharia Civil) - COPPE; Universidade Federal do Rio Janeiro, Rio de Janeiro, 2005.

MOHAN, T. P.; KANNY, K. Chemical treatment of sisal fiber using alkali and clay method. Composites: Part A, Kidliton, v. 43, p.1989-1998, 2012. 
PADILHA, J.; TOLEDO FILHO, R. D.; LIMA, P. R. L.; JOSEPH, K.; LEAL, A. Argamassa leve reforçada com polpa de sisal: Compósito de baixa condutividade térmica para uso em edificações rurais. Engenharia Agrícola, Jaboticabal, v. 21, p. 1-11, 2001.

RAMIRES, E. C.; MEGIATTO, J. D.; GARDRAT, C.; CASTELLAN, A.; FROLLINI, E. Biobased composites from glyoxal-phenolic resins and sisal fibers. Bioresource Technology, Essex, v. 101, $\mathrm{n}$. 6, p. 1998-2006, 2010.

RAUT, S.; RALEGAONKAR, R.; MANDAVGANE, S. Development of sustainable construction material using industrial and agricultural solid residue: A review of residue-create bricks. Construction and Building Materials, Guilford, v. 25, p. 4037-42, 2011.

SAVASTANO JÚNIOR, H.; AGOPYAN, V. Transition zone studies of vegetable fiber-cement paste composites. Cement and Concrete Composites, Barking, v. 21, p. 49-57, 1999.

SILVA, F. A.; CHAWLA, N.; TOLEDO FILHO, R. D. Tensile behavior of high performance natural (sisal) fibers. Composites Science and Technology, Barking, v. 68, p. 3438-3443, 2008.

TONOLI, G. H. D.; SANTOS, S. F.; SANTOS, J. A.; SANTOS, W. N.; SAVASTANO JÚNIOR, $\mathrm{H}$. Thermal performance of sisal fiber-cement roofing tiles for rural constructions, Scientia Agricola, Piracicaba, v. 68, n. 1, p. 1-7, 2011.

TOMCZAK, F.; SYDENSTRICKER, T. H. D.; SATYANARAYANA, K. G. Studies on lignocellulosic fibers of Brazil. Part II: Morphology and properties of Brazilian coconut fibers. Composites: Part A, Kidlinton, v. 38, p.1710-1721, 2007.

VALADEZ-GONZALEZ, A.; CERVANTES-UC, J. M.; HERRERA-FRANCO, P. J. Effect of fiber surface treatment on the fiber-matrix bond strength of natural fiber reinforced composites. Composites Part B, Kidlinton, v. 39, p. 309-20, 1999. 